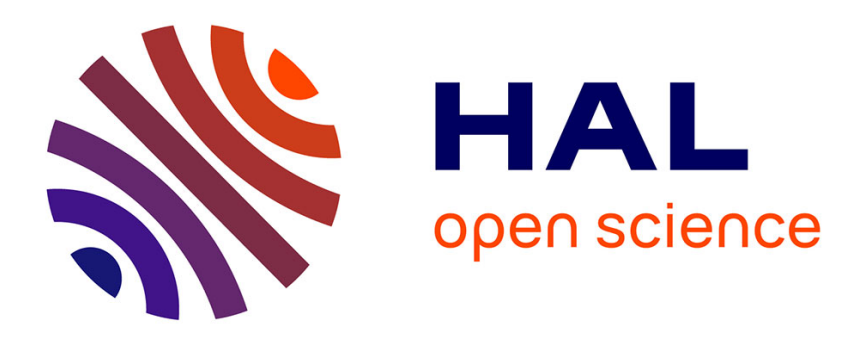

\title{
Mythical and symbolic origins of the city: The case of the Kathmandu Valley \\ Gérard Toffin
}

\section{To cite this version:}

Gérard Toffin. Mythical and symbolic origins of the city: The case of the Kathmandu Valley. Diogenes (Engl. ed.), 1990, 152, pp.101-123. 10.1177/039219219003815205 . hal-00592202

\section{HAL Id: hal-00592202 \\ https://hal.science/hal-00592202}

Submitted on 15 Feb 2018

HAL is a multi-disciplinary open access archive for the deposit and dissemination of scientific research documents, whether they are published or not. The documents may come from teaching and research institutions in France or abroad, or from public or private research centers.
L'archive ouverte pluridisciplinaire HAL, est destinée au dépôt et à la diffusion de documents scientifiques de niveau recherche, publiés ou non, émanant des établissements d'enseignement et de recherche français ou étrangers, des laboratoires publics ou privés. 


\section{MYTHICAL AND SYMBOLIC ORIGINS OF THE CITY: THE CASE OF THE KATHMANDU VALLEY}

"I seek the gold of time". André Breton, Point du jour.

In recent years, the relationships between systems of symbolic representations and cities have given rise to an often rich and stimulating consideration among various specialists in human sciences, namely, historians, anthropologists, semiologists and sociologists, among others. Urban conglomerates can no longer be conceived as simple assemblages of more or less functional constructions. The city is as much a mental concept as it is a physical reality. It is made up of images that give it a meaning. It does

Translated by Jeanne Ferguson 
not exist independently of the sum of subjective interpretations that are continually made by its inhabitants. Our Western perception of the city may be influenced by romanesque literature or the memory of a painting, in other words, by imaginary worlds. It varies according to individual memory: each of us is attached to the different urban spaces of his souvenirs, emotions arising from family history or the duration of a lifetime. These personal projections are all the more important because they command a certain number of daily actions and furnish a framework of orientation to every citizen. They contribute to giving a moral quality to urban space and transform physical objects into concepts, into more or less determined signs.

These symbolic devices seem even more decisive in cities of civilizations called traditional with a slow historical evolution and largely agrarian. In pre-industrial cities religious representations are essential to urban society. They intervene directly as regulating principles assuring the disposition of individuals within different groups. Here, religion is inserted into social life so deeply that it is not distinct from it or, better, it englobes all the rest. It intervenes at all levels, at the bottom as at the top of the social edifice. Moreover, religious ideas allow the citizens to find a place in a world conceived as closed and finite. Contrary to Western cities, the symbolic has, first, a collective dimension and second, an individual one. It is the object of a broad consensus and adhesion that must periodically be revived by a return to the sources. It would be audacious to affirm that such cities are perceived exactly in the same way by all their inhabitants, but most of the readings that can be made from the interior are clearly more limited than in the individualist societies in which we live. It is on this symbolization that we intend to reflect by taking the example of the cities in the Kathmandu Valley, in Nepal, typical ceremonial cities, touched by Westernization for only about thirty years. We want to make clear that this seat of a high culture, peopled by a strongly Indianized population, the Newar, is one of the most powerfully humanized and anciently urbanized zones of the Himalayas.

First of all, what is the origin of these cities? What do we know about their history? We have very little archaeological data on the urban spaces of this region, and scholars, reduced to meager 
indices, are still arguing about the exact location of the earliest capitals. Local archaeology is an embryonic discipline in Nepal and is especially linked to the preservation and restoration of religious monuments. Until now, no important excavation has been made in the cities of this high, rice-growing plateau. The rare digs opened here and there by foreign researchers have given few tangible elements and mostly concern the outlying sites with regard to the present towns, notably at Hadigaon. ${ }^{1}$ We know practically nothing of the original Kathmandu or Patan, their physical aspects, environment, the form of their first habitations. A consideration on the beginnings of urbanization seems all the more problematic, if not daring, since with a few exceptions the oldest constructions that have come down to us date only from the 12 th-13th centuries, a period in which it seems urbanization was already well established. ${ }^{2}$

However, two other ways are open: that of royal chronicles, which mention a certain number of myths of origin, and that of epigraphs. The first were composed in the 19 th century within

\footnotetext{
1 Some results of excavations in S.B.DEO, Archaeological Excavations in Kathmandu: 1965, Kathmandu, HMG, Department of Archaeology, 1966 (on Gairi Dhara and Hadigaon) and in C.S. Antonini and G. Verardi, "Excavation in the Kathmandu Valley", Ancient Nepal, 1985, no. 89, pp. 17-30 (on Hadigaon and Dhumvarahi). Even the four stupas of Pâtan that surround the city are difficult to date for the lack of excavations; cf. on this subject, F.R. Allchin, "A Note on the 'aśokan' stûpa of Pâtan", in The Stûpa, Its Religious, Historical and Architectural Significance, ed. by A.L. Dallapiccola, Wiesbaden, Franz Steiner Verlag, 1980, pp. 147-155. The latest results from the excavations at Ismeo, led by $\mathrm{G}$. Verardi, attest however the existence of a small royal city already well established at the beginning of the Christian era, perhaps even before, at Hadigaon (Harigaon) with a palace and Hindu religious elements. This city, which in all probability was one of the capitals of the Licchavi kings, fell into decadence toward the 11th century, following an unknown catastrophe (fire or earthquake). Today we find nothing but a big village, on the periphery of the "Great Kathmandu". Cf. G. Verardi, Harigaon Satya Nârâyana, Kathmandu. A Report on the Excavations Carried Out in 1984-1988, Rome, Ismeo, 1988.

2 A general presentation of these cities in G. Toffin, "La notion de ville dans une société asiatique traditionnelle: l'exemple des Néwar de la vallée de Kathmandou', L'Homme, 1982, XXII, 4, pp. 101-111, and N. Gutschow, Stadtraum und Ritual der newareschen Städte im Kathmandutal, Stuttgart, Kohlhammer, 1982. See also for Kirtipur, R. Herdrick, Kirtipur, Stadtgestalt Prinzipien der Raumordnung und geselleschaftliche Funktionen einer Newar-stadt, Munich, Weltforum Verlag, 1988. Some historical data in D.R. Regmi, Ancient Nepal, Delhi, F. Mukhopadhyay, 1961, and Dhanavajra Vajracarya, "The Development of Early and Medieval Settlements
} 


\section{Mythical and Symbolic Origins of the City}

the entourage of the royal families, apparently taking up older traditions transmitted orally. The second go back to the Licchavi era (5th-8th centuries) and are relatively abundant. Without giving decisive proof, they allow a number of hypotheses to be stated. Now, these two kinds of material, some of which concern mental realities and others material realities, explain the origin of urban sites in a radically different manner: the accounts of origin present the city as an ex nihilo creation, while the inscriptions make us think that it was created, at least in some cases, through a consolidation of villages. We must first take up this variance and through it examine the main characteristics of the towns under consideration.

\section{THE MYTH OF FOUNDATION}

According to the royal chronicles, the three main cities of the "Valley", all ancient royal cities, were each created by a particular king. Patan, apparently one of the oldest sites, was founded in the 7th century by King Birdeva; Kathmandu in the 10th century by King Gunakâmadeva; Bhaktapur in the 12th century by Ânanda Malla.

The myth of Patan's foundation tells the story of a peasant known for his ugliness who had the habit of going to cut herbs at Lalita-vana, a little woodland near the present temple of Kumbheśvar. One day this man bathed in a small pool that was in the woods. He was greatly surprised when he got out of the pool transformed into a splendidly handsome young man. Another surprise: the staff he had stuck in the ground by the pool before his bath stayed fixed in the earth: impossible to pull it out. Informed of this prodigy, King Birdeva introduced this man into the court and gave him the surname "Pretty", Lalita. The following night the

in the Kathmandu Valley. A Review of the Inscriptional Evidence', Heritage of the Kathmandu Valley, ed. by N. Gutschow and A. Michaels, Sankt Augustin, VGH Wissenschaftsverlag, 1987 , pp. 357-364. On the Licchavi capital, or capitals, $\mathrm{cf}$. M. Witzel, "On the Location of the Licchavi capital of Nepal" Studien zur Indologie und Iranistik, Cologne, Verlag A.U.J. Wezler, 1978, pp. 311-337, and M. Slusser, Nepal mandala. A Cultural Study of the Kathmandu Valley, Princeton, Princeton University Press, 1982, Vol. I, ch. 5. 
sovereign had a vision: the god Sarveśvara revealed to him the sacred name of the pool in the Lalita-vana woods (Gauri kund tîrtha) and the existence, nearby, of a linga stuck in the ground. The god ordered the sovereign to found on this emplacement (which corresponds to the present temple of Kumbheśvar) a city named Lalita-pattana, "The Pretty City." The king obeyed. He sent Lalita to the site to establish a settlement large enough to shelter 20,000 inhabitants. The palace was built in the center over an underground reservoir where the former herb-gatherer went regularly to venerate the serpent gods Nâga, dispensers of rain and fertility. Around the palace Lalita built eight religious buildings (mani: "jewels") in honor of particular deities. He also built a dharmaśâlâ (monastery) to the glory of the three hundred and thirty million gods who people the universe, and named it Lalitpur. ${ }^{3}$

The two other myths of foundation are much shorter. Regarding Kathmandu, the chronicles report that King Gunakâmadeva, whose capital was at Patan, had a dream: the goddess Mahâlaksmî appeared to him and ordered him to build a city in the form of a saber ( $\mathrm{khadga}$ ) at the confluence of the Bagmati and the Vishnumati, at the exact place, of a great purity, where the god Kâmeśvara lived. The king willingly complied with these instructions. He built at the indicated spot a large city, which was first called Kantipura, and raised a statue in honor of Laksmî. The city, which had 18,000 houses, became a renowned commercial center. Gunakâmadeva established a place for cremation to the west and had a statue of Candeśvara built in the center. He also founded sanctuaries in honor of Nila-Kâli to the east, Pacali Bhairava to the south and Manamaijupițha and Lattipitha to the north, as well as a temple for Nava Durgâ. ${ }^{4}$

\footnotetext{
${ }^{3}$ On the myth of the origin of Patan, cfr. especially D. Wright, History of Nepal, Calcutta, Ranjit Gupta, 1966, pp. 90-91, which presents the most complete version. See also N. Gutschow, "Pâtan: Historical Development, Spatial Structure and Ritual Topography", in Patan City, Innsbruck, Universitätsverlag Wagner, 1981, ("Khumbu Himal") p. 262. We note that this myth refers to the Nepali name (Lalitpur) for the city and not to its Newar name (Yela), much older. On Patan in the 11th-13th centuries, see B. Kölver and H. Sakya, Documents from the Rudravarnâ-Mahâvihâra, Pâtan. 1. Sales and Mortgages, Sankt Augustin, VGH Wissenschäftsverlag, 1985.

4 Ct. B.J. Hasrat, History of Nepal, Hoshiarpur, V.V. Research Institute Book
} 


\section{Mythical and Symbolic Origins of the City}

As for Bhaktapur, the chronicles tell us even less. They limit themselves to saying that King Ânanda Malla, after having ceded his throne to his oldest son, went west and founded a city called Bhaktapur, with 12,000 houses. He established a temple there in honor of Annapûrnâ Devî and the Nava Durgâ. Then in rivalry with his brother, he crossed the mountains and with the help of the goddess Candeśvarî founded seven villages: Banepa, Panauti, Nala, Dhulikhel, Khãdpu, Chaukot and Sanga. ${ }^{5}$

These accounts could be considered as fantasies by "pure" historians (and rightly so if we keep to the chronology). Nevertheless, they give precious indications on the way the city was conceived and the way it became part of the Nepalese mental universe. What do they tell us? The city was first of all defined by its ruler. As in the Indian world, urbanization is considered above all a royal act: no city worthy of the name without a king, no king without a recognized capital. The very structure of the city, built around the palace, names royalty as an eminent coordinator. The Nepalese chronicles stress the role of the sovereign by presenting the creation of cities as ex nihilo foundations: the urban ensemble already appears endowed with a fixed number of houses.

In two out of three cases, this foundation is due in the second place to divine intervention. The king creates the city on the instructions of a god, or more often a goddess, on a site already consecrated by some supernatural prodigies or by a remarkable religious monument. The center of the city is not only the seat of political power; it also contains the temple or sanctuary of a tutelary god. This temple-palace duality is essential to the ideal city and played a key role in the concrete exercise of power, as the chronicles tell us, during the entire Malla period (13th to 18 th centuries). As in many Asian civilizations, at the origin of the city there is the sacred place of the king's dwelling and/or that of a particular deity.

Agency, 1970, p. 46; and S. Levi, Le Népal, étude historique d'un royaume hindou, Paris, E. Leroux, 1905-1907, Vol. 1, pp. 52-53. Here too the myth mentions only the Nepal name of the city (Kântipur or Kathmandu) and not the Newar name (Yem).

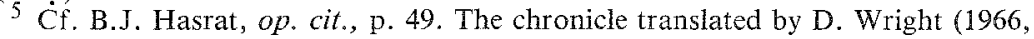
p. 110) states that it was at the instigation of the goddess Annapûrnâ that Bhaktapur was founded. 
In the third place, the king has to build other religious monuments outside or inside the walls to sanctify the city. If necessary, he brings in deities from the exterior. The disposition of these temples leads to a certain ordering of the city, a shaping of its religious topography. This symbolic structurization of space is accompanied by the inauguration of great communal festivities (Bisket jâtrâ, Matsyendranâth jâtrâ, Indra jâtrâ) in which the myth of origin of the settlement is acted out and consolidates the urban society around religious values.

Finally, we note that at Shaktapur the foundation of the city is accompanied by the creation of surrounding villages. This is a recurrent fact in the chronicles: the villages are often founded by the decision of the king, once the capital is established. The city is first, which in a way is obvious, since it is beginning with the moment the cities are built that the villages appear as such in the consciousness of the people. Mythical history begins with the foundation of urban settlements. The genesis of the city reproduces the genesis of the kingdom and marks the victory of humanity over natural elements.

This assimilation of the city to the "civilized" world governed by the laws of dharma appears clearly in the myth of the origin of the valley. According to this account, after having emptied the water in the basin, Mañjuśrî, the civilizing hero, built a great city for his faithful between the temple of Svayambhûnath and that of Guhyśvarî. Enclosed by high walls, the city had eight entrances disposed in the eight directions of the universe. In the center Mañjuśrî built a palace with four golden doors, encrusted with precious stones and decorated with the eight good luck signs, astamangala. In front of this central building, he erected a chrystal pillar surmounted by a golden lion. He named his city Mañjupattana, after his own name, and installed a king, Dharmakar, recommending him to pay daily devotions to Svayambhûnâth and Gunyeśvarî. ${ }^{6}$ We clearly see that in these representations urbanization is imposed as an original fact of the history of humanity. It is through the city, and not through the country, that man tames

\footnotetext{
${ }^{6}$ See B.J. Hastat for this myth, op. cit. pp. 3-32. A more detailed analysis in G. Toffin, Société et religion chez les Néwar du Népal, Paris, Ed. du CNRS, 1984, pp. 51-53.
} 
primitive nature: it is through the city that he appropriates a territory-here the nepâlkșetra-and sanctifies it.

\section{From the VILlaGe TO THE CITY}

Behind these accounts of foundation are hidden other realities. On the sites of Kathmandu and Bhaktapur, we have found several artifacts (small stupas, reservoirs, fountains) and inscriptions that antedate the creation postulated by the chronicles and attest to the earlier presence of human settlements. Still more interesting: the Licchavi inscriptions and certain manuscripts of the 13 th-14th centuries give place names that refer to pre-existing localities. For example, for M. Gutschow and B. Kölver, Bhaktapur would have been formed by the coalescence of several villages that were developed on that spot around the 3rd century A.D. ${ }^{7}$ Unfortunate$1 y$, the names of these localities have not come down to us. According to these two authors, the oldest part of the city was located in the east, in what is today the "upper city" (thâne) around the quarter of Taehapal. The city was then progressively extended toward the west, along a commercial road, absorbing the villages one after the other. ${ }^{8}$

The pre-existence of villages seems more clear at Kathmandu. The inscriptions and manuscripts mention three localities: Kolìgrâma, Dakshinakolîgrâmadranga and Vaidyagrâma, which date from the Licchavi period (5th-8th centuries). ${ }^{9}$ The first would have been located on the present emplacement of Kel toi, along the east-west commercial road where the town arose; the second, a village of some importance, was located in the south; Vaidyagrâ-

7 N. Gutschow and B. Kölver, Bhaktapur; Ordered Space Concepts and Functions in a Town of Nepal, Wiesbaden, Franz Steiner Verlag, 1975, p. 20.

8 Idem. p. 20.

9 See especially D. Vajracarya, "The Development of Early and Medieval Settlements in the Kathmandu Valley...", op. cit. The Sanskrit word pura (city) does not exist in the Licchavi inscriptions. We find only grâma (village), dranga (federation of villages around a commercial center) and tala (grouping of villages). However the inhabitants of the center of the valley were qualified as paura (citizens) as opposed to those of the periphery and hills called jânapada, one meaning of which is "peasant". 
ma extended southwest of Asan tol. ${ }^{10}$ Kolîgrâma was originally the northern part of the town, known in Newari as Yambû (from the Newariyã or yem: north); ${ }^{11}$ Dakshinakolîgrâmadranga in the southern part called Yamgala, a word whose etymology is unknown to us. When the city became unified it took the name of Yambû, which gave Yem, the present Newari name for Kathmandu. The word yamgala disappeared in the 18th century; we find it today only in the name of a fountain (Yangal hiti) located in the southern part. ${ }^{12}$

These processes of "synecism" are well known in southeast Asia and elsewhere. Pagan, ${ }^{13}$ Chittagong, developed in this way, by the clustering of villages around a center. Perhaps it is due to this ancient phenomenon that we must attribute the strongly rural aspect that the three ancient capitals of the Kathmandu Valley conserve today. At Bhaktapur $(48,000$ inhabitants) the most rural of the three cities, the majority of the inhabitants $(62.8 \%)$ is made up of farmers of the Jyâpu caste, and $60 \%$ of the population draw their income mainly from agriculture. ${ }^{14}$ Among them, the merchant and religious castes are themselves landowners and have their fields cultivated by Jyapu tenants, according to the current dispositions in the villages. In spite of the transformations brought about since 1960 by the rise of tourism and rapid Westernization of life styles, Kathmandu (180,000 inhabitants) and Patan (65,000 inhabitants) also comprise, or until recently comprised, an important proportion of rural quarters where one can breathe country air, especially on the outskirts. These "farmer-citizens" continue to lead a life subjected to the rhythm of agricultural occupations and go to work in the fields encir-

\footnotetext{
${ }^{10}$ M. Slusser, op. cit., pp. $87 s q$. For a critical point of view on this use of Nepalese sources, see K.P. Malla, "The Limits of Surface Archaeology", Contributions to Nepalese Studies, 1983, Vol. 11, no. 1, pp. 125-133.

11 M. Slusser, idem.

12 M. Slusser, idem. p. 89. On the genesis of Kathmandu, see also N. Gutschow, "Kâthmându: Historical Development, Spatial Structure, Social and Ritual Topography,", in Kathmandu City, Innsbruck, Universitätsverlag Wagner 1976 ('Khumbu Himal", 13/3, pp. 247-256.

13 See D. Lombard, "Pour une histoire des villes du Sud-Est asiatique", Annales E.S.C., 1970, no. 4, p. 847.

${ }_{14}$ R.I. Levy, Mesocosm, Hinduism and the Organization of a Traditional Newar City in Nepal, 1989, p. 105.
} 


\section{Mythical and Symbolic Origins of the City}

cling the town, which contradicts the definition, often taken up later, given by the geographer Jean Brunnes at the beginning of the century: "A town exists every time the majority of the inhabitants pass most of their existence and spend the principal part of their activity within the settlement." 15 At Patan and Bhaktapur, the furnishing of agricultural products is done in part by the citizen-farmers. Numerous industries for the transformation of the products of the earth which are situated in urban centers, electric mills, oil presses, etc., reinforce the rural activity, paradoxical to our Western eyes, accustomed to a separation between town and country.

Nevertheless, there are no major differences between the urban habitat and the rural habitat: the architectural elements, the kinds of construction, the dynamics of the conglomerate are the same in both cases. Here as there, we find the same ramified network of streets, most often intersecting at right angles, the same interior courtyards bordered by houses, the same brick pavements. Of course, the human density is slightly less in the villages, but the alternation of buildings and public or semi-public spaces answer to the same principles. This harmony between town and village, found in many Asiatic societies, is characteristic of the habitat of the Kathmandu basin.

We note in this regard that the urban quarter $(t o l)$ and the village (or the village quarter for the rural localities of some importance) are defined by the same elements: 1) a square central court called nani that serves as a place to dry agricultural products or possibly a small commercial center; 2) a temple to the god Ganesa to whom the inhabitants of the quarter come to render homage before each family ritual and on the occasion of festivals; 3) a temple of Nâsa dya, the local god of music, venerated by the groups of musicians of the quarter and by all the inhabitants during certain important ceremonies; 4) places of discharge chwâsa connected with the rituals of exorcism and curing; 5) itineraries of specific funeral processions that lead to the places of cremation outside the limits of the settlement. ${ }^{16}$

15 Quoted by M. Sorre, Les Fondements de la géographie humaine, Paris, Armand Colin, 1952, Vol. III, p. 178.

16 See N. Gutschow and B. Kölver, Bhaktapur, op. cit., p. 26. 
In his Sketches from Nepal $(1880) \mathrm{H}$. Holdfield reports that at each tol was associated a city gate; the inhabitants of the quarter were charged with its maintenance and defense against potential enemies. ${ }^{17}$ During the Malla period, the quarter was also invested with a certain authority in the matter of taxation. According to D.R. Regmi, "The tol of the urban centers corresponded to the basic administrative district, like the villages in the rural zones". ${ }^{18}$ When the royal power weakened, as was the case with Patan in the 18th century, the head men of the quarter (pradhân) held the essential posts of municipal power. On the whole, the urban quarter worked, and to a certain degree still works today, like an autonomous symbolic and social unity. It has such an important role in the identity of the citizen that the inhabitants have sometimes developed (or preserved) as in certain villages, particular dialects and ways of life which make them easily identifiable.

\section{ORGANIC OR PLANNED DEVELOPMENT}

Contrary to what is suggested by the texts of foundation cited in the chronicles, certain towns in the Kathmandu Valley seem to have been born from earlier villages. This process continues today: in the southern part of the valley the growth of villages and the increasing density of the built-up areas cause a "synecism" comparable in every way to what apparently happened before on the sites of present large urban centers. We will go further: the constant development of urbanization gives us reason to think that some years from now the two cities of Kathmandu and Patan, only 3.5 kilometers apart, will form one sole megalopolis.

Is there a contradiction between the two opposed versions of the birth of cities, ex nihilo growth or growth through coalescence of villages? It would be more correct to see two complementary processes, two phases in the appearance of urbanization. If

17 H.A. Oldfield, Sketches from Nepal, part 1, Delhi, Cosmo Publications, 1974, pp. 95-96 (first edition, 1880).

18 D.R. Regmi, Medieval Nepal, part 1, Delhi, F. Mikhopadhyay, 1965-1966, p. 514. 
the present large cities came from the agglomeration of primitive villages, it is nevertheless due to the action of a particular king that the city is founded. The chronicles do not entirely deform the reality: for a city to have been established there had to be at a given moment in history a king who gathered the inhabitants of his capital around a common image. The king imposed this image by applying a religious model drawn from Hindu and Buddhist cosmogonies. The palace occupied a central position linked by secret passages to the temples of the goddesses (Mâtrikâ) and Bhairava placed along the periphery in the eight directions of space. The idea of the city thus corresponds to a geometric plan, which leads us to think of the sacred diagrams of the mandala, yantra or even cakra type used by the Buddhist and Hindu priests in their rituals. Furthermore, pictorial representations exist of the cities in question in the form of mandala which attest to the importance of these plans, at least among the educated population. ${ }^{19}$ Definitively, the city of the Kathmandu Valley is distinguished from the village in that it constitutes a symbolic whole, an image of the cosmos, a reproduction of an englobing socio-cosmic order. And the walls that formerly enclosed it were as much military ramparts as enclosures figuring the limits of the world. It is in this perspective that the urban phenomenon in Nepal finds its real meaning.

There remains the problem of dates. How far back do these accounts of origin and the religious topography underlying them go? We must be vigilant on this point. By all the evidence, the myths of foundation preserve the memory of ancient events, but they were seemingly not elaborated until quite recently, no doubt around the 15th or 16th centuries. It is in this period, apogee of the civilization of the valley, that the definitive symbolic ordering of these towns dates. Although tantrism was introduced in the 10th-11th centuries in the region we are considering it is during the second Malla period (15th-18th centuries) that shaktism received the official patronage of the kings, becoming a veritable state religion, and that the series of the eight Mâtrikâ sur-

19 B. Kölver, "A Ritual Map from Nepal", in Folio rara, Steiner Verlag, 1976, pp. $68-80$. 
rounding the cities were put into place. ${ }^{20} \mathrm{We}$ must also keep in mind that during these three centuries the valley was divided into three independent and rival kingdoms. The religious architecture, the organization of the urban space profited greatly from this atmosphere of competition: the sovereigns had the same monuments built as those of their neighbors. It was a question of their prestige and the status of their city. Here we touch on the political function of these myths: the accounts of foundation had as an objective not only the furnishing of a religious model for the royal settlements; they also aimed at ordering a society under the protection of the sovereign and affirming the authority of the royal power in the face of concurrent kingdoms.

We then understand better how organic growth and planned growth were articulated over the centuries. The ordered and organized aspects of the urbanization of the valley have been greatly exaggerated. Of course, the ancient inhabitants of this region were acquainted with the treatises on architecture vâst $\hat{u}-s$ sâstra in use in India. ${ }^{21}$ But they probably were only used for religious monuments, palaces and the spaces around them. If we keep to the urban complexes, these towns are characterized more by an inextricable network of alleys, a disordered confusion of interior courtyards. As soon as the harmony of the facades was passed, the arbitrary and necessary reigned. Straight lines are rare, the dynamics confused. The checkerboard patterns hide an involuntary architecture where we hardly sense an organized thought. The recurrence, often pointed out, ${ }^{22}$ of the square spaces in the interior courtyards as in the buildings is a fact too universal to be explained directly by the Indian treatises on architecture. It attests especially to a profound aesthetic sense and a taste for harmonious proportions. If there was planning, it is therefore limited by the laying out of the principal streets, perhaps following

20 D.R. Regmi, Medieval Nepal, Vol. II, Calcutta, Firma K.L. Mukhopadhyay, 1966 , p. 576.

21 See M. Slusser, op. cit., Vol. 1, p. 93 and Vol. 2, pp. 108-110.

22 See N. Gutschow, "Courtyard Buildings in Nepal. The Palaces, Temples and Monasteries of the Newars", in A.L. Dallapiccola (ed.), Vijayanagara, City and Empire, New Currents of Research, Wiesbaden, Franz Steiner Verlag, 1985, pp. 362-379. 
destructions provoked by earthquakes. It could only be approximate, a posteriori, and superimposed on older elements.

As we have shown in the results of an inquiry on a small town near Bhaktapur, the real source of this urbanism is located within what could be called the "lineage sphere". ${ }^{23}$ Like the classical Indian city ${ }^{24}$ the Nepalese city, or better, Newar, from the name of the original inhabitants of the valley, is constituted beginning with groupings of houses belonging to the same family group. The dynamics of the urban tissue appears largely dictated by the process of extension and fragmenting proper to the family. The citizen remains as dependent on his family as the villager in his village. His autonomy proves to be limited.

\section{FESTIVE LITURGIES AND URBAN SPACE: INDRA JÂTRÂ}

Now we will return to the symbolic bases of these cities. As we have seen, the foundation of an urban site generally involves the installation of a great annual festival, jâtrâ (from the Sanskrit yâtrâ, "procession"'). These sumptuous liturgies, still celebrated today, reinforce the unity and religious structure of the city. Let us consider the Indra jâtrâ, the most important collective festivity of Kathmandu, one of the most colorful and spectacular of this high plain of the Himalayas. It is held in August-September at the end of the rainy season and mobilizes all the citizens for a week. According to a Hindu tradition, it was established by Gunakâmadeva, the king-founder of Kathmandu. ${ }^{25}$ It would be impossible to treat it in its totality; we will give here only the aspects relative to the urban scene and the social order of the city. But first, here are the terms used by Sylvain Lévi at the beginning of the century to describe the festivities in his masterly book on Nepal:

\footnotetext{
23 V. Barré, L. Feveile, P. Berger and G. Toffin, Panauti, une ville au Népal, Paris, Berger-Levrault, 1981.

24 See B.B. Dutt, Town Planning in Ancient India, Calcutta and Simla, Thacker, Prink and Co., 1925, p. 147.

${ }_{25}$ N. Gutschow, "Kạthmâṇ̣u: Historical Development, Spatial Structure, Social and Ritual Topography", op. cit. p. 250. See also S. Levi, supra.
} 
"The month of Bhâdrapada ends with the orgies of the Indra-yâtrâ. It is in Kathmandu that it has the most brilliance. Indra is the patron of the city and the Gurkas love the souvenirs that these festivities remind them of. It is again Gunakâma, the founder of Kathmandu, who is held to be the creator of the Indra-yâtrâ. It lasts eight days, from the 11 th Bhâdrapada sudi to the 4th Âsvina badi. The day is spent in visiting the temples and feasting. In the evening the dancers of caste gather before the palace, disguised as women, demons and animals, and dance until a late hour. The crowd runs to see this spectacle, interspersed with farces and clowning. The dancers receive a rather derisory recompense from the government. All over the city can be seen the figures of Indra, with his arms extended and marked on his forehead, hands and feet with religious signs (tilakas). The Capuchins of the 16th century thought they saw a transvestment (naturally Manichean) of Christ on the cross. These figures, mounted on trestles or under temporary shelters, are consecrated to the memory of defunct ancestors and are invoked in their name'" ${ }^{26}$

Thus, the god Indra is at the center of the festival. In ancient India this divine figure was closely associated with royal functions. Indra is the king of the gods and the world. He is the prototype itself of the sovereign. He has the warlike, dominating, dynamic aspects. The king is his representative on earth; some texts even affirm that he can attain the condition of king of the gods if he remains faithful to his duties. More generally, Indra is linked to the second order, varna, of Hindu society, that of the Kșatriya. He is the incarnation of secular and military power. He is represented as a warrior god, young and courageous. His strength is prodigious. He has the body of an athlete, no one is greater than he. He has a golden chariot attached to two horses. In his right hand he holds a club. He reduces the fortresses and the strongholds of the enemies. He is a great warrior, the support of the soldiers; he incarnates brute force.

The local myth, on which a large part of the festival is based, gives a slightly different image of Indra. According to that legend, the king of the gods went one day to the Kathmandu Valley to gather the flowers of the parijat tree (Nyctanthes arbo-tristis Lin.), a variety of jasmine, for his mother. Indra descended into the

26 S. Levi, op. cit., Vol II, p. 53. 


\section{Mythical and Symbolic Origins of the City}

valley hidden in a cloud. Unfortunately, a Kathmandu peasant surprised him at the moment he was stealing the flowers in the Maruniti quarter. The god was taken prisoner and exposed to the eyes of the population for seven days, his arms tied to a pole. The eighth day, Indra's mother, worried about the absence of her son, also went to Kathmandu. The king realized his error and proposed to Indra to release him on two conditions: that the god come back to the capital every year to be exhibited as a prisoner and that he furnish the peasants sufficient fog and dew in winter so that the crops would mature. Indra accepted. He was venerated by the crowd, then he and his mother mounted his white elephant Airâvata at Kilagal and left the inhabitants of Kathmandu near the temple of Nardevî, located at the western limits of the city.

Indra thus appears to the inhabitants of Kathmandu as a thieving god, $k h \tilde{u} d y a$. Apparently the Newari accentuate his meteorological function, linked to prosperity and fertility. Indra, god of rain, of storm, master of the clouds and thunder in Hindu tradition, is he not especially venerated by the Jyâpu farmers, who make up most of the population? ${ }^{27}$ But we must take a second look at this. In reality, theft is also an attribute of the king; he must do all in his power to defend and enlarge his kingdom. As for imprisonment, it is one of the risks he must run in his position. Likewise, Georges Dumézil recalled that, like other highranking Hindu divinities, Indra is sometimes described as a thief, especially of inebriating drink, due to which man surpasses himself, or of the ritual plant, soma, considered in Vedic texts as a god-king. ${ }^{28}$ The Malla kings of the Kathmandu Valley were identified as being closely linked to this god during the Indra jâtrâ and were affirmed in the eyes of the citizens as the support of universal order. They profited by the presence of Indra on earth, kept in captivity by their subjects, to assimilate his sacred power and extend their authority over the city. This is no doubt why a statue of Indra, usually kept in the temple of one of the tutelary gods of the royal family, was set on the throne of the king,

27 G. Toffin, "l'Indrâ jâtrâ à Pyangaon: essai sur une fête newar de la vallée de Kathmandou", L'Ethnographie, no. 76, 1978, pp. 109-137.

28 G. Dumézil, La religion romaine archaïque, Paris, Payot, 1974, (revised second edition), p. 196. 
at Nasal Chok, during the festival. ${ }^{29}$ In this particular case, the identification of the king with his divine prototype is total.

The presence of Indra during the festival is also symbolized by a pole about 25 meters high, erected before the ancient royal palace in the center of the city. This pole bears a banner on which are painted the signs of good luck, astamangala. It is raised on the 12th day of the month Bhâdra (August-September), the clear fortnight, at a propitious moment determined by the astrologers, in the presence (at least in the past) of high state dignitaries. It is lowered eight days later, the 4th day of Âśvin (SeptemberOctober), the dark fortnight, and immersed in the neighboring river. Branches and fruit, symbols of fertility, as well as small national flags are fixed on its top. At its foot is placed a small cage in which Indra, mounted on his elephant, is represented with his arms outstretched, bound with ropes as a sign of captivity. This holy image, surrounded by the eight divine Mothers, Asta Mâtrikâ, is venerated daily by a Brahman priest attached to the royal family. In this way the Indra jâtrâ reinforces the central location of the palace, a direct solicitation and coordinating organism of the urban society.

In scholarly literature, this pole, called indradhvaja, the banner of Indra, symbolizes the victory of the sovereign over his enemies. It is so closely associated with royalty that any unlucky incident that relates to it (a flight of a vulture around its summit, for example) risks bringing misfortune to the king and threatening his kingship. There is more: this pole represents the cosmic pillar that supports the universe and the axis mundi linking Heaven and Earth. Its name is yasim, a word derived from the Newari word yalasi, which designates the sacrificial stake which in Hinduism has a very marked cosmogonic connotation. This rapport is not by chance. We know that in ancient India the pole of Indra was a royal attribute and allowed the sovereign to communicate with the gods. This pole was placed at the summit of a pyramid at the exact center of the king's residence. ${ }^{30}$ Through

29 An Introduction to Hanuman Dhoka, Kathmandu, INAS, Tribhuwan University, 1975, p. 20.

30 J. Gonda, "Ancient Indian Kingship from the Religious Point of View", $\mathrm{Nu}$ men, 1955-1957. 


\section{Mythical and Symbolic Origins of the City}

this play of metaphors between microcosm and macrocosm, the palace merged with that of Indra in heaven. It acquired a cosmic dimension.

The festival is not confined to the center of the city. It also concerns the city's limits, formerly marked by walls. The first day of the festival, once the pole is raised, a funeral procession makes the rounds of the old city in a clockwise direction. Everyone of a pure caste who has had a death in the family during the year must take part. They carry incense, make offerings of rice in the temples located on the itinerary of the procession. The untouchables, who live outside the city, follow the procession and beg for money. This rite may formerly have had the function of leading the souls of the dead toward the hereafter and establishing a tightly closed boundary between the world of the living and that of the dead. But like all Newari circumambulations, its primary aim is to oppose an inner urban space, pure, sanctified and peaceful to an external space, impure, savage and dangerous. On the one hand, the religious route holds and envelops; on the other, it expels and keeps out. This dichotomy crosschecks a right/left polarity: when the procession makes the rounds of the city, the untouchables are confined to the left, impure, the pure castes to the right.

\section{THE LIVING GODDESS KUMÂRî, QUEEN OF THE CITY}

Another element of the festival seems essential to our subject. This is the Kumârî jâtrâ, the festival of the living goddess Kumari, which forms a relatively independent part of the Indra jâtrâ. Who is Kumârî? This little girl, chosen from the high Buddhist caste when she is two years old, is a manifestation of the tutelary god of the former Malla kings, Taleju. A veritable symbol of royalty, she has particular ritual relationships with the sovereign. Her house of finely carved wood is located right next to the former royal palace, at Basantapur, and from the moment of selection, watch is kept to see that her horoscope is compatible with that of the king. Kumârî lives surrounded by Buddhist and Hindu priests who render her homage at regular hours. She cannot leave her princely dwelling except for certain festive rituals important 
to the life of the city. She is replaced when she reaches the age of puberty. ${ }^{31}$

The fourtheenth day of Bhâdra, the clear fortnight, the living goddess takes her place in a wooden chariot especially built for her. This ceremonial chariot, mounted on four massive wheels, is drawn by means of ropes to the "lower" part of the city, a part corresponding to the down-stream of the nearby river. The day after, day of the full moon, the goddess makes the rounds of the "upper" part of Kathmandu, simulating the upstream. The third day of Âśvin, the dark fortnight, Kumârî's chariot is drawn through the central part of the city, attached to the royal palace. According to tradition, this third procession was installed in the 18 th century by Jayaprakâśa Malla, so that his favorite concubine could see the procession from her house at Kilagal. Kumârî is accompanied in these peregrinations by two little boys, also numbers of a high Buddhist caste, and perched in the same way on chariots. One represents Ganeśa, the other Bhairava. It is worth noting that the two parts, "high" and "low", covered during the first two days, correspond to the primitive nuclei of the city, Yambû and Yamgala, beginning with which Kathmandu developed. The festival of Kumârî is therefore modeled on the urban history of the city and affirms the unity of the different components of the royal capital.

Let us continue the analysis. These processions follow an itinerary which designs the form of a saber, $k h a d g a$, on the ground, the insignia of royalty and warlike power. ${ }^{32}$ Now, in the myth of foundation it is exactly on the model of a saber that the goddess Mahâlakșmî ordered King Guṇakâmadeva to construct Kathmandu. The procession of Kumârî thus immerses the capital in its time of origin. It recalls the primitive image of the city, dictated by the goddess, and revives a very old sacred geography: the past becomes the present and guarantees the future. One of the functions of these liturgies is to refresh, at least momentari-

\footnotetext{
31 The ethnographic dossier constituted by M. Allen, The Cult of Kumârî, Kathmandu, INAS, Tribhuwan University Press, 1975, is still today the most complete on this very particular cult in Nepal.

32 See R. Pradhan, Domestic and Cosmic Rituals Among the Hindu Newar of Kathmandu, Nepal, Delhi, Department of Sociology, 1986, Ph. D.
} 


\section{Mythical and Symbolic Origins of the City}

ly, the symbolic contours of the city. The constructed and architected system is charged with meaning.

But the crucial moment of the Kumârî jâtrâ comes on the last day, just after the third procession. On that day the living goddess solemnly gives her blessing to the king. Seated on her throne, she applies a mixture of rice and cinnabar thickened with sour milk $(\sinh a)$ on the forehead of the sovereign. Then she puts a garland of flowers around his neck. The king, inclined before her, gives her a gold piece (daksinâ) in exchange as though he had before him the priest of a real god. This ritual, today the end of the Indra jâtrâ, renews the power of the king. Each year, at the end of the rainy season, the little goddess renews the royal charge. Kumârî is only the visible aspect of the tutelary god Tajelu, who is hidden from the eyes of the profane. And the entire ritual can be seen as a transposition in broad daylight of a secret tantric ceremony uniting the king and Taleju. ${ }^{33}$ Here we are touching on the Hindu conception of royalty. In fact, in this system of thought, King Kṣatriya needs a feminine association to legitimize his authority and make his power fertile. ${ }^{34}$ Now, it is precisely the Goddess, generally assimilated to the earth, support of the kingdom, who assumes this function. The Goddess in all her forms: Mahâlakșmî, Taleju, Kumârî. From which come the singular relationships, almost carnal, that the king, master and husband of the earth, has with her. In many ways, it is the Goddess who governs the kingdom. It is she who symbolically appropriates the urban space during the Indra jâtrâ. The king is only her husband, her devotee, her representative, her servant. The Goddess helps him choose his capital as is explicitly specified in the myths of foundation, but she also gives him the power, sakti, that is in her, and victory over the enemy. Royalty is her gift, a gift that must be renewed every year. These beliefs are firmly anchored in the mind. The Nepalese royal house watches

\footnotetext{
33 The thesis was developed in G. Toffin, "Les aspects religieux de la royauté néwar au Népal", Archives de Sciences Sociales des Religions, no. 48, 1979, pp. 53-82. ${ }^{34}$ Indian parallels in F. Bhattacharya, "La déesse et le royaume selon le Kâlaketu Upâkhyâna du Canḍ̂n Mangala", Purusârtha, 5, 1981, pp. 17-53, and M.C. Porcher, "La princesse et le royaume sur la représentation de la royauté dans le Daśakumâracarita de Dandin", Journal Asiatique, Vol. CCLXXIII, 1985, pp. 183-207.
} 
the slightest expressions of the living goddess, looking for some premonitory signs, lucky or unlucky, relative to its future. Everyone likes to tell the story that in 1955 Kumârî put the sacred mark on the forehead of the crown prince Mahendra instead of on the king at the time, Tribhuwan. This latter died six months later and his son Mahendra was crowned.

This ritual of renewal of the royal power comes especially at a time of disturbances, contestations and license. During the festival anarchy reigns in the capital. The demons who had apparently dethroned the gods dance in the streets and threaten the universe. The people gather in certain parts of the city and openly criticize authority. The citizens improvise little comic scenes, $k h y a ̂ l a$, that take a political or religious personality, a rich merchant or a well-known person as a target. This period of unrest is not limited to the festival; it extends through the entire month preceding the Indra jâtrâ. The festival of the cow, Gâi jâtrâ, which takes place at the beginning of the month of Bhâdra, comprises numerous elements of license and symbolic overthrow of authority. It opens the period of the dances of demons, lakhe, in the whole valley. Order is restored only by the rite of consecration accomplished by Kumârî. The renewal of royal power thus puts an end to the anarchy that threatened the kingdom. The demons disappear, criticisms cease. Thanks to the goddess the king issues from the ordeal with restored power. And an entire community is reunited in the same victory over the powers of evil.

\section{THE GESTURE OF FOUNDATION}

Urban space and royalty are solidly linked in the Indian world. By restructuring the space of the locality, the great royal liturgies redefine the social order placed under the protection of the king and the gods. In this, the Newar city is inseparable from a hierarchized social structure whose sovereign appears as the great organizer and lawmaker (with the assistance of Brahman priests). It holds between the lines a grammar of political power that the collective festivities put into practice. After having redefined the limits of the city by means of processions, the Indra jâtrâ also forcefully reaffirms the dual centrality of the king and his tute- 


\section{Mythical and Symbolic Origins of the City}

lary god at the heart of the settlement. In Newar civilization, as almost everywhere in the Indian subcontinent, the palace and the temple, that of Taleju (Kumârî) in this case, are the two indivisible centers of the city. Depending upon whether one attaches oneself to the properly ritual plan or to that of political efficacy, one of the two poles predominates.

We must stress the importance of the symbolic. The Newar urban space is "informed", if we may put it that way, by the motivating ideas of Hinduism and Buddhism. It is never possible to define, or speak of, a quarter without a religious concept, a divinity, a ritual in the foreground of the analysis. The invisible aspects have as much reality as the visible aspects. The cities of the Kathmandu Valley are signs with which the gods strew the earth in order to celebrate their glory and their design. They reflect a supernatural and transcendent order. In such conditions, how can the space of the city be neutral? It expresses certain polarities, moral values; it has a cosmogonic quality. Through a complex use of allegories whose mainspring it would be wise to analyze in detail, the palace of the king is identified with that of the celestial city. The oscillation between the myth and the architectural system is constant. It is in this way that the topographical space is metamorphosed into a symbolic territory and becomes a system of signs.

The regular return to the time of the beginning plays an essential role in this regard. Every year, the myths of origin are tirelessly repeated and acted out in the ancient Malla capitals. Every year great processions take on a past with well-defined geographical limits and find the traces of enclosures that today have disappeared. The city draws new strength and rejuvenation from this and issues revived for a new annual cycle. Furthermore, by opening its text of foundation at fixed dates, the city is reconstituted as an oriented whole grouped around the sanctuaries and the palace. It is redefined as an enclosed space, separated from the neighboring countryside by symbolic boundaries. Internal quarrels are certainly not forgotten: with the aid of alcohol, they even double in intensity. But it is a matter of channeled ritual struggles, collective exorcisms, in a way. On the whole, the urban liturgies cause a movement of cohesion and regenerate a collective "we". During those days, groups that are usually closed 
open and mix. A link is constituted between a fabled past, very present in the mind, and the actual present. Like many preindustrial settlements around the world, the cities of the Kathmandu Valley cannot not relive those inaugural moments. The cyclic time to which they are attuned causes the alternations of disintegration and renaissance; such a symbolization must occur. A symbolization that seeks to perpetuate an immemorial dream, to deny history, without ever being able to totally achieve this goal.

Gérard Toffin

(C.N.R.S., Paris) 